DOI:

УДК 66.098:004.942

К.В. Гаценко, асп. каф. ХTHP, barannik katya@mail.ua,

В.О. Стросва, к. фіз.-мат. н., доцент, vikastroeva@ukr.net

Дніпровський державний технічний університет, м. Кам'янське

\title{
МАТЕМАТИЧНЕ МОДЕЛЮВАННЯ ВПЛИВУ УЛЬТРАЗВУКУ НА ОСНОВНІ ПАРАМЕТРІВ МЕТАНОУТВОРЕННЯ
}

3 використанням методів математичного моделювання було досліджено пріоритетні технологічні умови проведення біохімічних прочесів. Отримані моделі можуть слугувати інструментом для впливу на наступні прочеси отримання біогазу та біодобрив.

Ключові слова: субстрат; метанове бродіння; ультразвукова обробка; кавітація; параметри зброджування; рН; метаногенні бактерії; кінетика процесу; біогаз.

Using the methods of mathematical modeling, the priority technological conditions of biochemical processes were investigated. The obtained models can serve as a tool for influencing the following processes for obtaining biogas and biofertilizers.

Keywords: substratum; methane fermentation; ultrasonic treatment; cavitation; fermentation characteristic; pH; methanogenic bacteria; process kinetics; biogas.

\section{Постановка проблеми}

В даний час в світі на вироблення електричної енергії і тепла низького і середнього потенціалу витрачається основна частина видобутих паливно-енергетичних ресурсів. Негативні тенденції розвитку традиційної енергетики обумовлені наявністю двох факторів - швидким виснаженням природних ресурсів і забрудненням навколишнього середовища. За даними $\mathrm{OOH}$, виснаження покладів вугілля передбачається в 2082-2500рр. Технології традиційної енергетики підвищують ефективність використання енергоносіїв, але не поліпшують екологічну ситуацію. У зв'язку з цим виникла необхідність раціонального використання ресурсів традиційної енергетики з одного боку і розвиток технологій з використання нетрадиційних і відновлюваних джерел енергії - з іншого. Загострення екологічних проблем, виснаження запасів традиційних енергоресурсів, обумовили глобальний інтерес до розробки і використання технології біоконверсії органічних відходів для отримання енергії. Одним із шляхів утилізації органічних відходів $€$ анаеробне зброджування, яке забезпечує знешкодження відходів і збереження продукту як знезараженого високоякісного органічного добрива при одночасному отриманні біогазу, що містить близько $70 \%$ метану.

\section{Аналіз останніх досліджень та публікацій}

Під час зброджування в сировині розвивається мікрофлора, яка послідовно руйнує органічні речовини до кислот, а останні під дією синтрофних і метаноутворюючих бактерій перетворюються в газоподібні продукти. Надзвичайно важлива утилізація біомаси в сільському господарстві, де на різні технологічні потреби витрачається велика кількість палива і безперервно зростає потреба у високоякісних добривах. Отримання біогазу економічно виправдано і $є$ кращим при переробці постійного потоку відходів. Отримання біогазуособливо ефективно на агропромислових комплексах, де існує можливість повного екологічного циклу $[1, \mathrm{c.68}]$.

Ультразвукова обробка органічних відходів відноситься до способів електрофізичної обробки сировини. Для виявлення шляхів використання ультразвукового впливу на сировину в сільському господарстві необхідно розглянути механізм дії ультразвуку і його вплив на основні фізико-хімічні процеси. Встановлено, що дія ультразвукових коливань проявляється в тому випадку, коли спостерігається ефект кавітації. Поширення акустичних коливань здійснюється шляхом періодичного стиснення і розрядження середовища. Поширюючись в рідкому середовищі, акустичні хвилі викликають появу змінного звукового тиску. При зниженні тиску до величини, що перевищує поріг міцності даної рідини, настає явище кавітації. Воно полягає в то- 
му, що в результаті тимчасового зниження тиску в певному обсязі всередині рідини утворюються кавітаційні порожнини, заповнені газами і парами цієї рідини. Підвищення тиску призводить до зменшення порожнин і повного їх зникнення, а виникаючі при цьому сферичні хвилі кінцевої амплітуди, що поширюються в рідині, перетворюються в ударні хвилі 3 локальними імпульсами тиску порядку сотень атмосфер, що супроводжуються потоками з величезними градієнтами швидкостей. Це є причиною руйнівної дії [2, с.157].

Ультразвукові процеси засновані на виникненні кавітації. Кавітація супроводжується електричними процесами і випромінюваннями в ультразвуковій частині спектра, що є однією 3 причин хімічної дії ультразвуку. Хімічні процеси, що протікають в полі ультразвукових хвиль, різноманітні. Кавітація зумовлює виникнення практично всіх хімічних реакцій, які спостерігаються в даному середовищі. Це пов'язано не тільки зізначним утворенням кавітаційних порожнин, а й з їх здатністю до резонансних періодичних пульсацій. Кавітаційна бульбашка під дією акустичних коливань зароджується протягом напівперіоду розрядження, якщо гідростатичний тиск знижується до пружності пари, тобто рідина виявиться сильно розтягнутою. У наступний напівперіод відбувається стиснення і виникнення бульбашки. Якщо при такому стисненні не відбудеться його повне захлопування, то при певних ії розмірах бульбашка починає пульсувати в такт з частотою акустичних коливань [3, с. 28-30.].

Більшість досліджень присвячено питанню, який з факторів, що становлять ефект кавітації, має основний вплив на перебіг хімічних реакцій. Розглянемо деякі фактори, що впливають на ефект ультразвукової кавітації, і пов'язаний з нею вплив ультразвуку на хімічні і фізикохімічні процеси [4].

При проведенні фізико-хімічних процесів під впливом ультразвуку правильний вибір частоти може відігравати вирішальну роль для досягнення оптимальних результатів, в той час як на хімічні реакції зміна частоти коливань впливає мало.

Хімічні реакції в рідких середовищах не відбуваються при інтенсивності нижче порога кавітації. Вище цієї межі швидкість реакції збільшується більш-менш пропорційно підвищенню ультразвукової інтенсивності. Дослідники встановили, що існує оптимальна інтенсивність, яка збігається з максимальним утворенням бульбашок кавітації,при ії перевищенні число кавітаційних бульбашок зменшується [5, с. 23-26].

У більшості фізико-хімічних процесів максимальний ефект впливу проявляється в перші 10-30 хвилин, збільшення тривалості впливу може викликати зворотну дію (наприклад, емульгування і коагуляцію). У деяких біохімічних процесах ефект впливу ультразвуку виявляється в перші 1-2 хвилини, подальша обробка також викликає зворотну дію (наприклад, ефект підвищення сходження насіння). Тому, в питанні фактора тривалості впливу потрібен індивідуальний підхід до кожного окремого процесу, так як певних закономірностей не встановлено [6, c. 203].

Зміна статичного тиску впливає на процес кавітації. При дослідженні перебігу хімічних реакцій в ультразвуковому полі було виявлено, що як підвищення тиску, так і зниження його нижче атмосферного викликає зниження ефекту впливу і навіть повне його припинення [7, c. 412].

Точно регулювати температуру рідини, що піддається впливу ультразвукових хвиль, важко, так як за рахунок поглинання ультразвукової енергії виділяється значна кількість теплоти. Оптимальною температурою фізико-хімічних процесів, що проводяться при впливі ультразвуку, вважають $10 \div 30^{\circ} \mathrm{C}$. При тривалому впливі ультразвуку і пов'язаному з цим підвищенні температури оброблюваних речовин за рахунок поглинання ультразвукової енергії потрібне охолодження розчинів [8, с. 350].

Таким чином, розглянуто дію ультразвуку на різні фізико-хімічні процеси, які можуть відбуватися при будь-якому виробництві. Ультразвук тільки починає знаходити своє застосування в харчовій промисловості. Останнім часом увагу дослідників привернула ультразвукова обробка сировини [9, с. 214]. 


\section{Формулювання мети дослідження}

Метою дослідження є збільшення виходу біогазу при анаеробній переробці органічних відходів шляхом інтенсифікації процесу зброджування субстрату в біореакторі з ультразвуковим впливом.

\section{Виклад основного матеріалу}

Вимірювання концентрації водневих іонів $\mathrm{pH}$ показали, що водний органічний субстрат, який має рН 6,3, після впливу ультразвуку змінює активність іонів водню до рН 7,6, тим самим сприяючи розвитку і життєдіяльності мікроорганізмів. Доцільність застосування даної обробки підтверджується експериментальними дослідженнями, представленими в табл. 1 та на рис. 1(a, б).

Таблиця 1. Характеристика рН водного органічного субстрату обробленого та не обробленого ультразвуком

\begin{tabular}{|c|c|c|c|c|}
\hline \multirow{2}{*}{$\begin{array}{c}T, \\
\text { діб }\end{array}$} & \multicolumn{2}{|c|}{ Сировина оброблена ультразвуком } & \multicolumn{2}{|c|}{$\begin{array}{c}\text { Сировина не оброблена } \\
\text { ультразвуком }\end{array}$} \\
\hline & $\mathrm{pH}$ & Вихід біогазу $Q, \mathrm{~m}^{3} \times 10^{-3}$ & $\mathrm{pH}$ & $\begin{array}{c}\text { Вихід біогазу } Q, \\
\mathrm{~m}^{3} \times 10^{-3}\end{array}$ \\
\hline 0 & 6,5 & 0 & 6,1 & 0 \\
\hline 1 & 6,52 & 1,2 & 6,13 & 0 \\
\hline 2 & 6,57 & 1,5 & 6,15 & 0 \\
\hline 3 & 6,61 & 1,7 & 6,17 & 0 \\
\hline 4 & 6,70 & 1,9 & 6,18 & 0 \\
\hline 5 & 6,83 & 2,1 & 6,2 & 0 \\
\hline 6 & 6,84 & 2,3 & 6,26 & 0,1 \\
\hline 7 & 6,86 & 2,5 & 6,29 & 0,3 \\
\hline 8 & 6,87 & 2,6 & 6,3 & 0,3 \\
\hline 9 & 6,87 & 2,7 & 6,35 & 0,4 \\
\hline 10 & 6,89 & 2,8 & 6,4 & 0,5 \\
\hline 11 & 7,04 & 2,9 & 6,46 & 0,5 \\
\hline 12 & 7,07 & 3,1 & 6,55 & 0,6 \\
\hline 13 & 7,11 & 3,3 & 6,67 & 0,65 \\
\hline 14 & 7,23 & 3,4 & 6,73 & 0,9 \\
\hline 15 & 7,31 & 3,5 & 6,8 & 1,2 \\
\hline 16 & 7,33 & 3,9 & 6,82 & 1,4 \\
\hline 17 & 7,35 & 4,8 & 6,85 & 1,6 \\
\hline 18 & 7,40 & 6,0 & 6,87 & 1,9 \\
\hline 19 & 7,42 & 7,8 & 6,89 & 2,1 \\
\hline 20 & 7,44 & 8,2 & 6,9 & 2,3 \\
\hline 21 & 7,45 & 8,8 & 6,93 & 2,4 \\
\hline 22 & 7,51 & 9,1 & 6,95 & 2,6 \\
\hline 23 & 7,52 & 10,2 & 6,97 & 2,75 \\
\hline 24 & 7,54 & 11,4 & 6,99 & 2,8 \\
\hline 25 & 7,55 & 11,7 & 7,01 & 2,8 \\
\hline 26 & 7,57 & 11,75 & 7,08 & 2,85 \\
\hline 27 & 7,57 & 11,8 & 7,12 & 2,85 \\
\hline 28 & 7,59 & 11,9 & 7,17 & 2,9 \\
\hline 29 & 7,61 & 12,0 & 7,21 & 3,0 \\
\hline 30 & 7,64 & 12,0 & 7,25 & 3,0 \\
\hline 31 & 7,67 & 12,1 & 7,26 & 3,1 \\
\hline 32 & 7,69 & 12,2 & 7,8 & 3,1 \\
\hline 33 & 7,73 & 12,3 & 7,3 & 3,2 \\
\hline 34 & 7,75 & 12,3 & 7,34 & 3,2 \\
\hline 35 & 7,77 & 12,3 & 7,38 & 3,2 \\
\hline
\end{tabular}




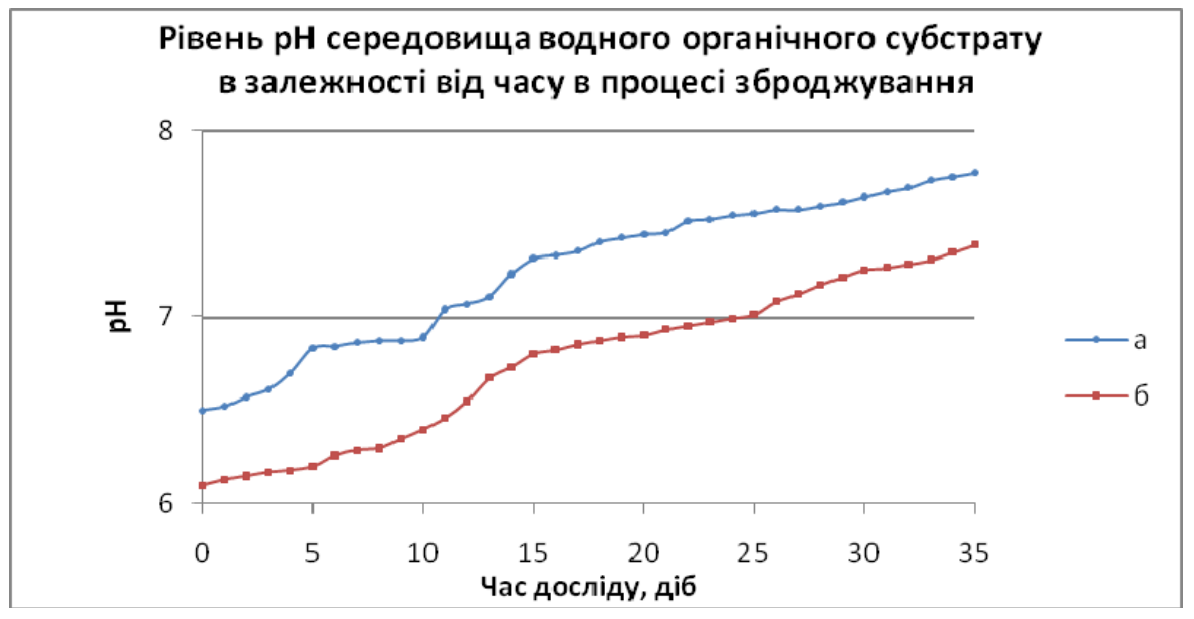

Рuc. 1. Зміна рН середовища в залежності від часу в процесі зброджування: а) сировина оброблена ультразвуком б) сировина, що не пройшла обробку

Наведеними вище дослідженнями встановлено, що напрямок і швидкість хімічної реакції в значній мірі залежить від водневого показника. Вихід біогазу залежить від кількості мікроорганізмів, вплив ультразвуку дозволяє прискорити процес зародження і зростання мікроорганізмів і збільшити їх кількість по всьому об'єму субстрату, що знаходиться в метантенку. Посилюючи здатність мікроорганізму продукувати метаболізм клітини, відкривається можливість підвищення швидкості росту і збільшення поверхні метаноутворюючих бактерій. Вплив ефекту ультразвуку на величину рН (рисунок $1(\mathrm{a}$, б)) представлено на графіках. Метаногенні бактерії функціонують лише в нейтральному середовищі (в інтервалі значень $\mathrm{pH}=6,5-7,5$ ). Як видно 3 графіка, на першомуетапі, в першій стадії бродіння,органічні речовини, які містятьсяувідходах під впливом анаеробної мікрофлорирозкладаються на складні органічніречовини (білки, вуглеводні та ін.), які трансформуються в органічні кислоти жирного ряду:спочаткуутворюються оцтова і масляна кислоти зі слідами валеріанової, мурав 'їної і капронової кислот. Велика кількість аніонів оцтової кислоти зменшує активну реакцію середовища $\mathrm{pH}$ до $6,5-6,0$, що призводить до зниження активності бактерій, які беруть участьу першій фазі бродіння. Відбувається так зване «закисання» середовища. Використанняультразвукудозволило знизити процес «закисання» до $\mathrm{pH}=6,4[10$, с.18].У другій (метановій) фазі метанові бактеріїрозкладаютьутворені кислоти, в результаті чого виділяється метан та вуглецевий газ, $\mathrm{pH}$ зростає до 6,7-7,5. Метаноутворюючі бактерії зброджують також етиловий спирт. При інших рівних умовах ультразвук дозволяє швидше досягти оптимального $\mathrm{pH}$ до рівня $6,8-7,5$, при чому відбувається максимальне виділення біогазу.

В рамках даного дослідження було поставлено завдання дослідження отриманих експериментальних даних 3 метою визначення виду залежності кількості виходу біогазу від часу та рівню $\mathrm{pH}$ середовища водного органічного субстрату, обробленого ультразвуком. У математичній постановці задачі в якості незалежних факторів прийнято $x_{1}$ - термін зброджування субстрату $\left(T_{\mathrm{i}}\right.$, діб) та $x_{2}$ - рівень $\mathrm{pH}$ середовища водного органічного субстрату (ум. од.), а в якості залежного фактору - y, функції відгуку (спостережуваної випадкової величини), приймаємо вихід біогазу $\left(Q, \mathrm{~m}^{3} \times 10^{-3}\right)$.

Для побудови математичної моделі $y=f\left(x_{1}, x_{2}\right)$ було застосовано теорію кореляційнорегресійного аналізу. 3 метою виявлення найкращого прогнозу було розроблено кілька моделей, а саме лінійну двофакторну та ряд нелінійних, для кожної з яких визначено основні параметри та оцінки. Порівняльна оцінка рівнянь регресії була проведена по значенням скорегованого коефіцієнта детермінації $R^{2}$, похибок прогнозу, стандартних похибок коефіцієнтів регресії, ймовірностей значимості коефіцієнтів моделей, а також за значеннями суми квадратів залишків. 
За отриманими результатами дослідження найкращою було визнано модель наступного вигляду:

$$
\widetilde{y}=b_{0}+\sum_{i=1}^{n} b_{i} x_{i}+\sum_{i j=1}^{n} b_{i} x_{i} x_{j}+\sum_{i=1}^{n} b_{i i} x_{i}^{2}+\ldots
$$

Зазначимо, що у цій моделі члени другої степені характеризують кривизну функції відгуку. Чим більше ії кривизна, тим більше в моделі членів вищих степенів. У нашому випадку це модель:

$$
\tilde{y}=b_{0}+b_{1} x_{1}+b_{2} x_{2}+b_{12} x_{1} x_{2}+b_{11} x_{1}^{2}+b_{22} x_{2}^{2} .
$$

Для відшукання її коефіцієнтів було застосовано метод найменших квадратів із попередньою лінеаризацією представленої нелінійної функції. В якості вихідних даних застосовано значення відповідних параметрів з табл. 2.

\begin{tabular}{|c|c|c|c|c|c|c|}
\hline $\begin{array}{c}\text { Вихід біо- } \\
\text { газу } Q, \\
\mathrm{~m}^{3} \times 10^{-3} \\
y\end{array}$ & $\begin{array}{c}T, \text { діб, } \\
x_{1}\end{array}$ & $\begin{array}{c}\mathrm{pH} \\
x_{2}\end{array}$ & $x_{1} * x_{2}$ & $x_{1}^{2}$ & $x_{2}^{2}$ & $\begin{array}{c}\text { Розрахов. } \\
\text { вихід } \\
\text { біогазу } \\
\widetilde{y}\end{array}$ \\
\hline 0 & 0 & 6,5 & 0 & 0 & 42,25 & 1,2781 \\
\hline 1,2 & 1 & 6,52 & 6,52 & 1 & 42,51 & 1,0237 \\
\hline 1,5 & 2 & 6,57 & 13,14 & 4 & 43,16 & 1,1946 \\
\hline 1,7 & 3 & 6,61 & 19,83 & 9 & 43,69 & 1,2519 \\
\hline 1,9 & 4 & 6,7 & 26,8 & 16 & 44,89 & 1,7737 \\
\hline 2,1 & 5 & 6,83 & 34,15 & 25 & 46,65 & 1,1126 \\
\hline 2,3 & 6 & 6,84 & 41,04 & 36 & 46,79 & 1,8543 \\
\hline 2,5 & 7 & 6,86 & 48,02 & 49 & 47,06 & 2,2924 \\
\hline 2,6 & 8 & 6,87 & 54,96 & 64 & 47,20 & 2,6114 \\
\hline 2,7 & 9 & 6,87 & 61,83 & 81 & 47,20 & 2,5499 \\
\hline 2,8 & 10 & 6,89 & 68,9 & 100 & 47,47 & 2,4847 \\
\hline 2,9 & 11 & 7,04 & 77,44 & 121 & 49,56 & 3,4563 \\
\hline 3,1 & 12 & 7,07 & 84,84 & 144 & 49,98 & 3,9289 \\
\hline 3,3 & 13 & 7,11 & 92,43 & 169 & 50,55 & 4,3605 \\
\hline 3,4 & 14 & 7,23 & 101,22 & 196 & 52,27 & 3,6981 \\
\hline 3,5 & 15 & 7,31 & 109,65 & 225 & 53,44 & 3,0843 \\
\hline 3,9 & 16 & 7,33 & 117,28 & 256 & 53,73 & 4,3183 \\
\hline 4,8 & 17 & 7,35 & 124,95 & 289 & 54,02 & 5,4451 \\
\hline 6 & 18 & 7,4 & 133,2 & 324 & 54,76 & 5,8581 \\
\hline 7,8 & 19 & 7,42 & 140,98 & 361 & 55,06 & 6,9528 \\
\hline 8,2 & 20 & 7,44 & 148,8 & 400 & 55,35 & 7,9404 \\
\hline 8,8 & 21 & 7,45 & 156,45 & 441 & 55,50 & 8,8676 \\
\hline 9,1 & 22 & 7,51 & 165,22 & 484 & 56,40 & 9,4773 \\
\hline 10,2 & 23 & 7,52 & 172,96 & 529 & 56,55 & 10,3304 \\
\hline 11,4 & 24 & 7,54 & 180,96 & 576 & 56,85 & 11,0111 \\
\hline 11,7 & 25 & 7,55 & 188,75 & 625 & 57,00 & 11,4415 \\
\hline 11,75 & 26 & 7,57 & 196,82 & 676 & 57,30 & 11,8472 \\
\hline 11,8 & 27 & 7,57 & 204,39 & 729 & 57,30 & 11,5375 \\
\hline 11,9 & 28 & 7,59 & 212,52 & 784 & 57,61 & 11,6077 \\
\hline 12 & 29 & 7,61 & 220,69 & 841 & 57,91 & 11,5707 \\
\hline 12 & 30 & 7,64 & 229,2 & 900 & 58,37 & 11,9261 \\
\hline
\end{tabular}

Таблиця 2. Матриця планування та результати дослідів 
Закінчення таблиці 2.

\begin{tabular}{|l|l|c|c|c|c|c|}
\hline 12,1 & 31 & 7,67 & 237,77 & 961 & 58,83 & 12,2693 \\
\hline 12,2 & 32 & 7,69 & 246,08 & 1024 & 59,14 & 12,0325 \\
\hline 12,3 & 33 & 7,73 & 255,09 & 1089 & 59,75 & 12,9190 \\
\hline 12,3 & 34 & 7,75 & 263,5 & 1156 & 60,06 & 12,5894 \\
\hline 12,3 & 35 & 7,77 & 271,95 & 1225 & 60,37 & 12,1526 \\
\hline
\end{tabular}

Отже, у результаті математичного моделювання було побудовано наступну нелінійну математичну модель:

$$
\tilde{y}=-5655.4-74.3 x_{1}+1730.9 x_{2}+11.4 x_{1} x_{2}-0.2 x_{1}^{2}-132.4 x_{2}^{2} .
$$

Обчислено коефіцієнт детермінації (найбільш розповсюджена статистика для оцінки якості моделі): $R^{2}=1-\frac{\sum_{i=1}^{n}\left(y_{i}-\tilde{y}_{i}\right)}{\sum_{i=1}^{n}\left(y_{i}-\bar{y}\right)}$, де $n-$ число спостережень, $\bar{y}=\frac{1}{n} \sum_{i=1}^{n} y_{i}-$ середнє значення залежної змінної, $\widetilde{y}$ - модельні (розраховані) значення, побудовані за оціненими параметрами

Для отриманої регресійної моделі $R^{2}=0,99$ має рівень значущості $\alpha=0,001$, отже надійність моделі $\gamma=1-\alpha=0,99$. Таким чином, з ймовірністю похибки не більше 0,001 рівняння регресії має вигляд (1). При цьому отримані рівні значущості кожного параметра моделі

$$
\begin{aligned}
& \tilde{y}=-5655.4 \quad-74.3 x_{1} \quad+1730.9 x_{2} \quad+11.4 x_{1} x_{2} \quad-0.2 x_{1}^{2} \quad-132.4 x_{2}^{2} \\
& \begin{array}{llllll}
(3.07 \mathrm{E}-08) & (2.04 \mathrm{E}-09) & (2.31 \mathrm{E}-08) & (1.95 \mathrm{E}-10) & (1.74 \mathrm{E}-08) & (1.39 \mathrm{E}-09)
\end{array}
\end{aligned}
$$

свідчать про надійність визначених коефіцієнтів.

Адекватність отриманої моделі перевірено за критерієм Фішера. Розрахункове значення критерію Фішера: $F=\frac{R^{2}}{1-R^{2}} \cdot \frac{n-k-1}{k},(k-$ число чинників в системі $)$, яке використовується для перевірки гіпотези про суттєвість відхилу від нуля вибіркового значення коефіцієнту детермінації отримано у вигляді $F=488.09$. Застосовуючи неперервну метрику для перевірки гіпотези для цього значення за допомогою засобів пакету статистики MS EXCEL розраховано рівень значущості. А саме, визначено ймовірність (рівень значущості), якому відповідає $F$ з $k$ та $n-k-1$ ступенями свободи з використанням статистичної функції $\operatorname{FPACП}(F ; k ; n-k-1)$. Отже, значимість $F$ : FРАСП $(488.09 ; 5 ; 36-5-1)=8.9 \mathrm{E}-28$. Таким чином, за результатами обробки експериментальних даних можна стверджувати, що з ймовірністю похибки не більше 0,001 (з надійністю висновків 0.99) коефіцієнт детермінації суттєво відрізняється від нуля, а рівняння регресії (1) статистично значимо і його можна використовувати для прогнозу.

\section{Висновки}

Розроблено математичну модель зміни $\mathrm{pH}$ у процесі отримання біогазу з водного органічного субстрату обробленого ультразвуком, що дозволить спрогнозувати та оптимізувати процес виробництва за рахунок регулювання рівня $\mathrm{pH}$, температури процесу бродіння та гранулометричного складу. Подальше дослідження робить можливим прогнозування виходу біогазу математичним шляхом без проведення довгострокових дослідів.

Науковий інтерес представляє розробка нової технології переробки органічних відходів, заснована на використанні ультразвуку в процесі зброджування субстрату, що дозволяє збільшити вихід біогазу. Вплив ультразвуку дозволяє змінювати $\mathrm{pH}$, що впливає на напрям і швидкість виходу біогазу з водного розчину органічного субстрату. Проведеними дослідами підтве- 
рджено факт збільшення виходу біогазу в 4 рази при обробці органічного субстрату ультразвуком, ніж без застосування ультразвукової обробки.

\title{
Список використаної літератури
}

1. Шомин А.А. Биогаз на сельском подворье. / Шомин А.А. // Харьков: Балаклея: ИИК «Балаклейщина». - 2002.

2. Кок У.Е. Звуковые и световые волны. / Кок У.Е. // М.: Мир. - 1966.

3. Маринченко В.А. Влияние ультразвуковой обработки солодового молока на его состав и качество зрелой бражки. / Маринченко В.А., Кислая Л.В., Исаенко В.Н., Антонов А.В., Усенко В.А. // Ферментная и спиртовая промышленность. - 1987. - № 5 - С. $42-47$.

4. Ультразвуковые процессы и аппараты в биологии и медицине. [Электронный ресурс].- «Все о звуке. Теория и практика. Ультразвук в биологии» - Режим доступа: http://www.uzo.matrixplus.ru/ultramedbio.htm (дата звернення: 15.10.2017).

5. Кулмырзаев А.А.Высокочастотный ультразвук в исследовании реологических свойств вязких материалов / Кулмырзаев А.А., Мачихин С.А., Дюшеева А.Д. // Хранение и переработка сельхозсырья. - 2003. - № 3 - С. 23-26.

6. Хмелев В. Н. Применение ультразвука высокой интенсивности в промышленности. Алт. гос. техн. ун-т, БТИ. - Бийск: Изд-во Алт. гос. техн. ун-та, 2010.

7. Шиляев, А. С. Ультразвук в науке, технике и технологии. Гомель: Инст. радиологии, 2007. $412 \mathrm{c}$.

8. Brian Lempriere Ultrasoundand Elastic Waves. AcademicPress. 2002. - 350 p.

9. Атрощенко Е.Э. Действие ударно-волновой обработки семян на морфологические особенности и продуктивность растений: автореф. дис. канд. биол. наук. 03.00.12. - М., 1983.

10. Костромин Д.В. Анаэробная переработка органических отходов животноводства в биореакторе с барботажным перемешиванием: автореф. дис. канд. техн. наук: 05.20.01. - М., 2010.

\section{MATHEMATICAL MODELING OF THE ULTRASOUND EFFECT ON THE MAIN PARAMETERS OF METHANE GENERATION (METHANOATING) Hatsenko K.V., Stroieva V.O.}

\begin{abstract}
At present, the bulk of the extracted fuel and energy resources is spent on the production of electric energy and heat of low and medium potential. Negative trends in the development of traditional energy are due to the presence of two factors - rapid depletion of natural resources and environmental pollution. According to the UN, depletion of coal deposits is expected in 2082-2500 years. Traditional energy technologies increase the efficiency of energy use, but do not improve the environmental situation. In connection with this, there was a need for rational use of traditional energy resources on the one hand and the development of technologies for the use of non-traditional and renewable energy sources - on the other. Aggravation of environmental problems, depletion of reserves of traditional energy resources, caused a global interest in the development and use of bioconversion technology for organic waste to generate energy. One of the ways to dispose organic waste is anaerobic digestion, which ensures the disposal of waste and preservation of the product as disinfected highquality organic fertilizer while receiving biogas containing about $70 \%$ of methane.

The purpose of the study is to increase the yield of biogas during anaerobic processing of organic waste by intensifying the process of digesting the substrate in a bioreactor with ultrasonic effect. The purpose of this study is to obtain experimental data to determine the type of dependence of the amount of biogas release on the time and $\mathrm{pH}$ level of the aqueous organic substrate environment treated with ultrasound.
\end{abstract}




\section{References}

[1] Shomin, A.A. (2002) Biohaz na celskom podvore [Biogas in the rural yard]. Kharkov: Balakleia [in Russian].

[2] Kok, U.E. (1966) Zvukovye I svetovye volny [Sound and light waves]. Moscow: Mir [in Russian].

[3] Marinchenko, V.A., Kislaia, L.V., Isaenko, V.N., Antonov, A.V. \& Usenko, V.A. (1987) Vliianie ultrazvukovoi obrabotki solodovoho moloka na eho sostav i kachestvo zreloi brazhki [The effect of ultrasonic processing of malt milk on its composition and quality of a mature beer]. Fermentnaia i spirtovaia promyshlennost - Enzyme and alcohol industry, 5, $42-47$ [in Russian].

[4] Ultrazvukovye protsesy $\mathrm{i}$ apparaty $\mathrm{v}$ biolohii i meditsine [Ultrasonic processes and devices in biology and medicine]. (n.d.) uzo.matrixplus.ru. Retrieved from http://www.uzo.matrixplus.ru/ultramedbio.htm [in Russian].

[5] Kulmyrzaev, A.A., Machikhin, S.A. \& Diusheeva, A.D. (2003) Vysokochastotnyi ultrazvuk v issledovanii reolohicheskikh svoistv viazkikh materialov [High-frequency ultrasound in the study of the rheological properties of viscous materials]. Khranenie i pererabotka selkhozsyria Storage and processing of agricultural raw materials, 3, 23-26 [in Russian].

[6] Khelev, V.N. (2010). Priminenie ultrazvuka vysokoi intensivnosti v promyshlennosti [The use of high-intensity ultrasound in industry]. Biisk: AltHTU [in Russian].

[7] Shiliaev, A.S. (2007) Ultrazvuk v nauke, nekhnike i tekhnolohii [Ultrasound in science, technology and technology]. Homel: Institut radiolohii [in Russian].

[8] Brian Lempriere. Ultrasound and Elastic Waves. Academic Press, 2002, p. 350.

[9] Atroshchenko, Ye.E. (1983) Deistvie udarno-volnovoi obrabotki semian na morfolohicheskie osobennosti i produktivnost rastenii [Effect of shock-wave seed treatment on the morphological features and productivity of plants]. Extended abstract of candidate's thesis. Moscow [in Russian].

[10] Kostromin, D.V. (2010) Anaerobnaia pererabotka orhanicheskikh otkhodov zhivotnovodstva v bioreaktore s barbotazhnym peremeshivaniem [Anaerobic processing of organic animal waste in a bioreactor with bubbling mixing]. Extended abstract of candidate's thesis. Moscow [in Russian]. 